\title{
Water contestations in the Little Karoo: Liaisons between the Calitzdorp irrigation board and the Calitzdorp (Kannaland) Municipality, 1912- 2013
}

\author{
WP VISSER ${ }^{2}$
}

\begin{abstract}
Although a good agricultural-yielding region when adequate rainfall is available the Little Karoo is plagued by regular, recurring and sometimes devastating droughts. In a rural town like Calitzdorp, where the same water resources are being shared by agricultural and domestic users, acute shortages over time have contributed to a history of water disputes and contestations between the Calitzdorp Irrigation Board (CIB) and the local municipality. The study focuses on the period between 1912, when the Calitzdorp Irrigation Board was established, and the beginning of the 21st century. Drought conditions and water shortages, also due to further municipal needs, were main determinants in relations between the CIB and the municipality between the 1950s and the early 1990s. Although this relationship had been abrasive at times up to 1994, issues regarding municipal water allocation and usage and payment of water tariffs had usually been settled in a practical way and to the mutual satisfaction of all stakeholders. The interests of the all-white CIB and town council were intertwined in a community whose existence depended on an agricultural economy supported predominantly by irrigation. However, when new district municipalities were created in 1998 the Calitzdorp Municipality was dissolved after 88 years and all executive and administrative municipal powers shifted to the neighbouring town of Ladismith. As a result of political instability, mismanagement and inefficient administration occurred. The new Kannaland Municipality not only demanded more water from the CIB, but also started paying its water bills in an erratic manner to the board. This situation led to the souring of relations between the two entities.
\end{abstract}

Key Words: Water contestations, droughts, Calitzdorp Irrigation Board, Nelsriver Dam, Kannaland District Municipality

\section{Introduction}

According to the World Economic Forum, quoted by Hedden and Cilliers, water scarcity now ranks as the third most concerning global risk. The National Development Plan notes that since South Africa is already a water-scarce country, greater attention will have to be paid to the management and use of water. The agricultural sector is the largest user of water,

$1 \quad$ Research for this article was made possible by the National Research Foundation. I am also indebted to the Department of Water and Sanitation and the Calitzdorp Irrigation Board for allowing me access to their archives and documents.

2. Prof. Wessel Visser is attached to the Department of History, University of Stellenbosch. Email: wpv@sun.ac.za. 
accounting for $57 \%$ of total water usage, while municipal demand accounts for $35 \%$ of water usage. Irrigated agriculture is the largest single consumer of water in South Africa, with around 1,6 million hectare equipped for irrigation. Although the 2014 Hedden and Cilliers report forecasted that the largest increase in water demand by 2035 would come from the municipal sector, ${ }^{3}$ the drought of 2015-2016 called for a re-focus on the vital importance of agriculture. As a result of the drought agricultural production and food security is under threat which could also lead to the collapse of the South African rural economy. According to Grain SA, only 48\% of the normal annual grain crop was planted during the 2015 planting season. Annually, about 200000 hectares of grain are irrigated but also in this sector the drought had a negative impact as water quotas were already diminished in certain irrigation districts. ${ }^{4}$ This dire situation underlines the importance of agricultural irrigation on the parched South African landscape.

In the preface of his seminal work on the rise of conservation in the country Beinart noted that the development of water management, inter alia, constitutes a major but neglected element in the history of knowledge and intellectual life in South Africa. ${ }^{5}$ Gouws echoes this sentiment by arguing that management of natural resources, such as water, demands an understanding of the complex connection of global, national and local management regimes within rapidly developing economic, political and institutional transformation. ${ }^{6}$ Internationally, the contestation and appropriation of water is not new and several studies focus on this aspect. ${ }^{7}$ Although a number of South African scholars since the 2000s began focusing on studies such as water management, the dynamics of water provision and water usage, the socio-environmental history of water, water user's associations and the construction of dams, to name but a few ${ }^{8}$, surprisingly little attention was paid hitherto to

S Hedden and J Cilliers, "Parched prospects. The emerging water crisis in South Africa", African Futures Paper 11, Institute for Security Studies, September 2014, pp. 1-2, 4-5.

See e.g. A van der Walt, “Op die rand van 'n tragedie”, Die Burger, 23.12.2015, p. 4.

W Beinart, The Rise of Conservation in South Africa. Settlers, Livestock, and the Environment 1770-1950, Oxford University Press, Oxford, 2003, p. xv.

CM Gouws, "The tragedy of the water commons: the case of the Lower Orange water management area", The Journal for Transdisciplinary Research in Southern Africa, Vol. 4, No. 1, July 2008, p. 256.

See e.g. J Franco, L Mehta and GJ Veldwisch, "The Global Politics of Water Grabbing”, Third World Quarterly, Vol. 34, No. 9, pp. 1651-1675.

See e.g. A Lumby, M Matete and J Rwelamira, "The management of South Africa's water resources with particular reference of the period 1956-1998", South African Journal of Economic History, Vol. 20, No. 2, September 2005, pp. 83-108; JWN Tempelhoff, "Water and the human culture of appropriation: the Vaal River up to 1956", The Journal for Transdisciplinary Research in Southern Africa, Vol.2, No. 2, December 2006, pp. 431-452; JWN Tempelhoff, V Munnik and M Viljoen, "The Vaal River Barrage, South Africa's hardest working water way: an historical contemplation", The Journal for Transdisciplinary Research in Southern Africa, Vol. 3, No. 1, July 2007, pp. 107-133; M Orne-Gliemann, 'Water users' associations from the users' perspective: local water management at Thabina irrigation scheme, Limpopo, South Africa", The Journal for Transdisciplinary Research in Southern Africa, Vol. 4, No. 1, July 2008, pp. 1-29; M Ginster, C Gouws, CM Gouws, H Mäki, R Mathipa, S Motloung, M Nyandoro and JWN Tempelhoff, "Views on unlawful water abstractions along the Liebenbergsvlei River, South Africa", The Journal for Transdisciplinary Research in Southern Africa, Vol. 6, No. 1, July 2010, pp. 1-24; L van Vuuren, "Together we can do more - environmental consciousness in the South African dam construction sector (1945-1980)", The Journal for Transdisciplinary Research in Southern Africa, Vol. 9, No. 1, July 2013, pp. 51-80; N Kruger, "A socio-environmental history of water in the 
aspects such as the hydro-politics of water contestations between water suppliers and water users in both rural and urban areas.

However, Musemwa's pioneering study, Water, History and Politics in Zimbabwe, focuses on water provision to the town of Bulawayo between 1894 and 2008. Musemwa investigated aspects such as perennial aridity, water scarcity as an anthropogenic phenomenon, water as a mechanism of social control and the fact that the control of water is crucial not only as an earner of revenue but also in affirming power in urban or rural governance. ${ }^{9}$ Quoting from work by Gandy and Swyngedou, Musemwa also argues that the close relationship between urban water infrastructure and the development of municipal governance appears to be one of the critical dynamics in the emergence of modern towns. Furthermore, he asserts that controlling the flow of water implies controlling a city or town, because without the uninterrupted flow of water, the city or town's metabolism would come to a halt. ${ }^{10}$

This article investigates the control and provision of, and contestation over water in the rural town of Calitzdorp situated in a semi-arid region of South Africa. The study focuses on the period between 1912, when the Calitzdorp Irrigation Board was established, and the beginning of the 21st century. Researching the topic the author also drew extensively on the archives of the Calitzdorp Irrigation Board between 1912 and 2006, as well as the archives of the Kannaland Municipality (previously known as the Calitzdorp Municipality) preserved in the Western Cape Archives and Records Service in Cape Town. ${ }^{11}$

\section{The historical development of Calitzdorp and the geographical features of its surroundings}

The rural town of Calitzdorp is situated in the foothills of the Swartberg Mountains in the semi-arid to arid Little Karoo and approximately $400 \mathrm{~km}$ east of Cape Town. The Little Karoo region lies in a broad east-west oriented valley between the Langeberg-Outeniqua

Karoo c. 1762-2012, with specific focus on Prince Albert and Williston”, Unpublished MA thesis, University of Stellenbosch, 2013.

M Musemwa, Water, History and Politics in Zimbabwe. Bulawayo's struggles with the environment, 18942008, Africa World Press, Trenton, 2014. See also M Musemwa, "Disciplining a 'dissident city': Hydropolitics in the City of Bulawayo, Matabeleland, Zimbabwe, 1980-1994", Journal of Southern African Studies, Vol. 32, No. 2, June 2006, pp. 239-254; M Musemwa, "Coping with water scarcity: The social and environmental impact of the 1982-1992 droughts on Makokoba township, Bulawayo, Zimbabwe", in F Locatelli and P Nugent (eds.), African Cities. Competing Claims on Urban Spaces, Brill, Leiden and London, 2009, pp. 157-185; M Musemwa, "Perpetuating colonial legacies: The postcolonial state, water crisis and the outbreak of disease in Harare, Zimbabwe, 1980-2009", in S Chiumbu and M Musemwa (eds.), Crisis! What Crisis? The multiple dimensions of the Zimbabwean crisis, HSRC Press, Cape Town, 2012, pp. 3-41; M Musemwa, "Water scarcity and the colonial state. The emergence of a hydraulic bureaucracy in south-western Matabeleland, Zimbabwe, 1964-1972", in LM Harris, JA Goldin and C Sneddon, Contemporary Water Governance in the Global South. Scarcity, marketization and participation, Routledge, 2013, pp. 79-94.

See M Musemwa, "Early struggles over water: From private to public utility in the city of Bulawayo, Zimbabwe, 1894-1924", Journal of Southern African Studies, Vol. 34, No. 4, December 2008, p. 882; Musemwa, Water, History and Politics in Zimbabrwe, pp. xxiii-xxiv. 
Mountains in the south and the Witteberg-Swartberg Mountains in the north. ${ }^{12}$ The first white settlers moved into the vicinity of modern day Calitzdorp by the middle of the eighteenth century where one Louis Fourie obtained the loan-farm Buffelsvlei by 1748. By 1757 this farm was granted to Jacobus Pretorius and by 1761 to Jacobus van Zijl. In 1813 the British colonial administration replaced the loan-farm system with the perpetual quitrent system and by 1821 the farm Buffelsvlei was registered in the names of the brothers JJ and MC Calitz. It was thus on Buffelsvlei, the farm of the Calitzses, that the town of Calitzdorp as it became known by 1845 , eventually developed on the banks of the Nels River. ${ }^{13}$

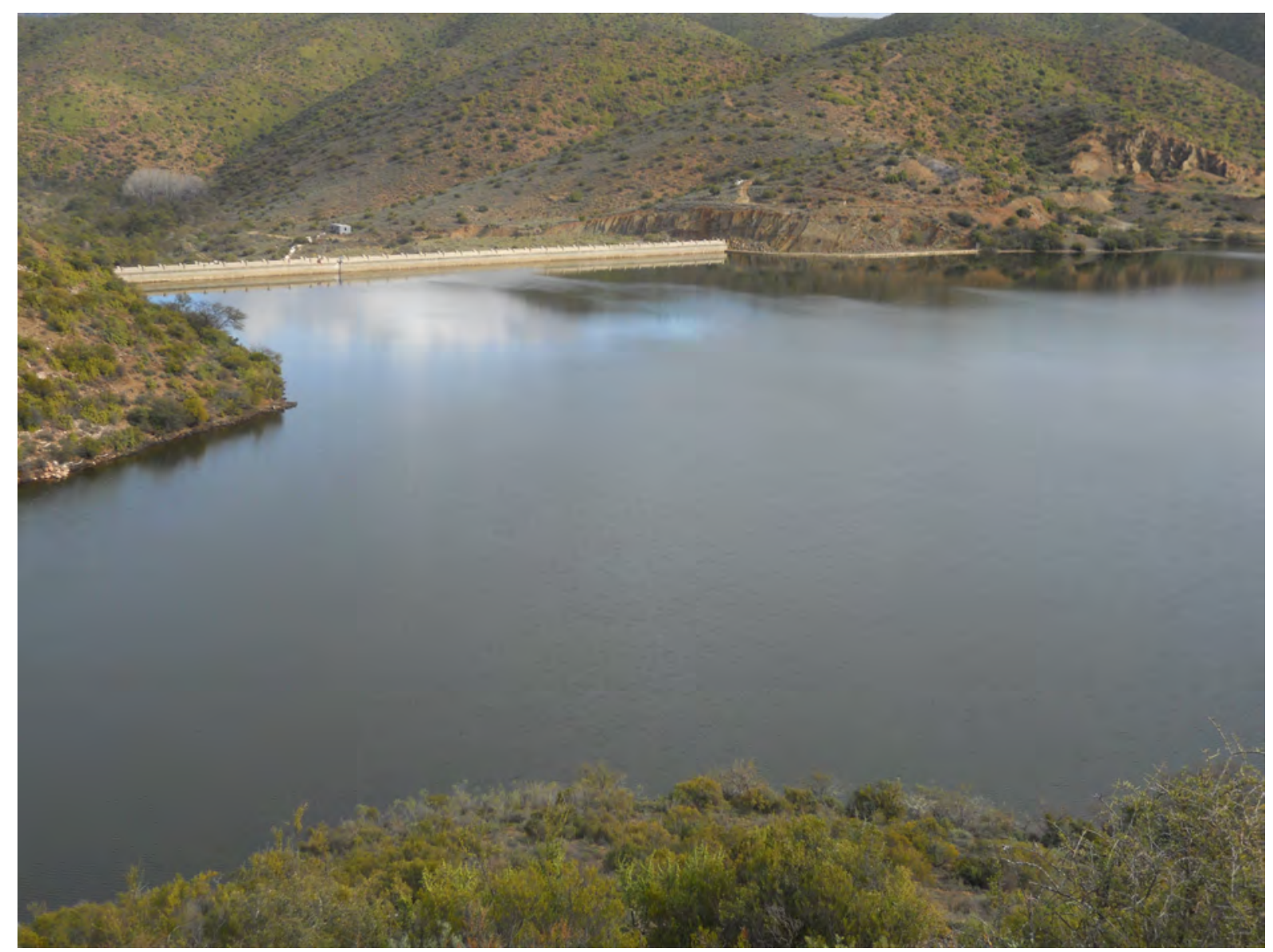

Illustration 1 Calitzdorp Dam. The spillway appears on the right end of the dam wall (Source: Author's private collection)

Three morgen of Buffelsvlei were sold for religious purposes in 1856. In 1857 a church was built on this land and plots were also sold by the church to members of the congregation. The first school building was erected in 1858. In 1873 the Calitzdorp Dutch Reformed Congregation was established independently from the Oudtshoorn congregation. Since 1896 a village management board existed and in June 1909 the farm Buffelsvlei was officially declared a municipal area, although full municipal status was granted to Calitzdorp only in

12 D le Maitre, C Colvin and A Maherry, "Water resources in the Klein Karoo: the challenge of sustainable development in a water-scarce area”, South African Journal of Science, 105, January/February 2009 , p. 39.

13 HC Hopkins, Ned Geref Kerk Calitzdorp 1873-1913, Nasionale Boekdrukkery Beperk, Elsiesrivier, 1973, pp. 10-18; JW Momberg, "Regionale studie van die distrik Calitzdorp", Ongepubliseerde MAtesis, Universiteit van Stellenbosch, 1948, pp. 85-88; M Roux, Huisvriend. 'n Informele Ondersoek, Calitzdorp Museum, Calitzdorp, 2013, pp. 28, 30, 34, 246, 312.

TD, 11(3), December 2015, pp. 186-207. 
1913. A railway line was extended from Oudtshoorn to Calitzdorp in 1924 and in 1937 the town was electrified. ${ }^{14}$

Much of the water used in the Little Karoo is sourced from catchments which are situated to the north of the Witteberg-Swartberg Mountain ranges. The Little Karoo is characterised by marked orographic rainfall gradients and rain shadow effects. Most of the low-lying central valley between the Langeberg-Outeniqua and the Witteberg-Swartberg Mountain ranges, where Calitzdorp is situated, receives $100-300 \mathrm{~mm}$ per annum. The Little Karoo has a quasi 10-12 year cycle: roughly five years with more and five years with less rainfall and a range of $10-30 \%$ on either side of the long-term mean. The mean summer daily temperature in February is $>30^{\circ} \mathrm{C}$ in the low lands. In addition, the potential evaporation is more than 2000 $\mathrm{mm}$ per year and exceeds $2250 \mathrm{~mm}$ per year in the dry central region. ${ }^{15}$ Momberg correctly observed that without irrigation agriculture would have been impossible in an arid district such as Calitzdorp. ${ }^{16}$

This article focuses on the Nels River (also known as the Cango River) ${ }^{17}$, in which the Calitzdorp Dam is situated, and its irrigation district. It is a perennial mountain river which sprouts from the Swartberg Mountains north of Calitzdorp. In general the soil in the Calitzdorp district is fertile although of divergent quality in places. Rich loamy and alluvial soils are found in the valleys of the Nels River and in the vicinity of the confluence of the Nels and Gamka rivers south of Calitzdorp. Tobacco, lucerne, lucerne seed, wheat, maize, barley, oats, walnuts, citrus, vegetables and deciduous fruit such as apricots, figs, pears, plums and quinces and especially Alberta peaches, are produced in this irrigation district. The cultivation of vineyards, however, represents the largest agricultural activity and wines are being produced. In recent years some farmers have also begun to cultivate olives. In terms of stock ostriches form the largest component while cattle, sheep, goat, pig and bee farming, as well as small-scale dairy farming also take place. ${ }^{18}$

A perusal of the historical literature on Calitzdorp reveals striking references to recurring droughts in the district since the nineteenth century: 1862, 1865-1866, 1868-1869, 1885, 1896, 1900, 1914-1915, 1923-1927, 1932-1933, 1937-1942, 1945-1947, 1950, 1954, 1959 1960, 1967 and 1999. ${ }^{19}$ Mention was also made of water restrictions in Calitzdorp during

Hopkins, Ned Geref Kerk Calitzdorp, pp. 18, 34, 37, 39, 41-42, 134-135; Momberg, Regionale studie van die distrik Calitzdorp, pp. 85-86, 91; A Appel, "Die distrik Oudtshoorn tot die tagtigerjare van die 19de eeu: 'n sosio-ekonomiese studie”, Argiefjaarboek vir Suid-Afrikaanse Geskiedenis, Vol. 51, Deel II, Staatsdrukker, Pretoria, 1988, pp. 138, 222-223, 226; Roux, Huisvriend, pp. 36, 81, 113, 132, 168, 187, 188; M Roux, Piet Strydom. Die Wêreld en Nalatenskap van 'n Calitzdorpse Bouer, Private Publication, Calitzdorp, 2012, pp. 28, 62, 67, 80-82.

Le Maitre, et al., Water resources in the Klein Karoo, pp. 39-41; Momberg, Regionale studie van die distrik Calitzdorp, p. 36.

Momberg, Regionale studie van die distrik Calitzdorp, pp. 16, 48.

Hopkins, Ned Geref Kerk Calitzdorp, p. 13; Roux, Huisvriend, p. 440.

Momberg, Regionale studie van die distrik Calitzdorp, pp. 9-10, 13, 23-24, 49-52, 54-55, 60-73; Hopkins, Ned Geref Kerk Calitzdorp, pp. 128-129; Appel, “Die distrik Oudtshoorn”, pp. 161, 190; Roux, Piet Strydom, pp. 69, 81; Roux, Huisvriend, pp. 182, 260.

See JC Brown, Water Supply of South Africa and facilities for the storage of it, Oliver \& Boyd, Edinburgh, 1877, pp. 389-390; Momberg, Regionale studie van die distrik Calitzdorp, pp. 49, 53, 60, 77-78, 62; Hopkins, Ned Geref Kerk Calitzdorp, pp. 65, 71, 78, 81, 126, 128; Roux, Piet Strydom, pp. 16, 69, 80, 82, 87; Roux, Huisvriend, pp. 47, 50, 176, 182, 187-188, 247, 252, 258, 282, 284, 377. 
some of these droughts. ${ }^{20}$ According to Hopkins and Momberg the serious periodic droughts determined the fate of the Calitzdorp community. Agricultural harvests were destroyed which led to poverty among farmers. ${ }^{21}$ The Standard Bank report on conditions during the 1915 drought elucidates: "...farmers have had to contend with one of the worst droughts experienced for many years, the rainfall for the past 6 months having been only 1.9 inches $[4.826 \mathrm{~cm}]$... reliance has to some extent to be placed on storm water. This year the usual summer floods did not come down the rivers and lucerne lands were badly affected. Farmers having sold their reserve stocks of dry lucerne to Government early in the year, have been left without feeding for their ostriches which are being kept alive on prickly pear, maize, etc. ...there has been heavy mortality among the birds here... Owing to the drought the orange crop has been poor... Prices for tobacco have ruled low... At present time there is no doubt that a good portion of the farmers in the district is practically insolvent". ${ }^{22}$ In 1906 already Acutt and Yorke Worthington concluded that in the then Cape Colony the growth of lucerne was not possible without irrigation. ${ }^{23}$

In November 1924, during the drought of 1923-1927, the Oudtshoorn Courant vividly reported about "...a terrific drought which has [Calitzdorp] in its grip. The drought is being severely felt in the area which forms the actual Municipality of Calitzdorp; but just below the township those broad fertile lands of Gamka are a dreadful sight to behold. What should be smiling lands of lucerne carrying hundreds of stock, - ostriches and cattle, are today drier and barer than a road. So terrific in fact is the drought that when the wind blows clouds of dust are raised from these lucerne lands...the drought has already robbed the district of thousands upon thousands of lbs [pounds] of grain and tobacco and will be the cause of the loss of many thousands of lbs of grapes and other grand fruit of the earth...the vines of most of which in the Gamka area have not even yet sprouted, and many on which in the Calitzdorp area the young grapes are dropping off'. ${ }^{24}$ And in 1947, during the drought period of 1945-1947, the grape harvest was torched by the sun and a great deal consequently lost due to a lack of sufficient irrigation water. ${ }^{25}$

Indeed, the South African Weather Service's rainfall statistics for the Calitzdorp Dam rainwater measurement station, kept between 1923 and 2004, more or less corroborate on the observations about periodic drought in the literature mentioned. The average monthly rainfall figure over this whole period amounts to $16.11 \mathrm{~mm}$ and affirms the climatological vulnerability of the Calitzdorp district. ${ }^{26}$ According to Le Maitre, Colvin and Maherry's calculations, most of the flow of the Calitzdorp Dam indicates extended periods (between

Momberg, Regionale studie van die distrik Calitzdorp, p. 91; Roux, Huisvriend, pp. 252, 255, 284, 292.

Hopkins, Ned Geref Kerk Calitzdorp, p. 98; Momberg, Regionale studie van die distrik Calitzdorp, pp. 77-78.

Quoted by Roux, Huisvriend, p. 69.

L Acutt and R Yorke Worthington, "Report on visit to Cape Colony of Mr. Leonard Acutt, Member of Natal Land Board, and Mr. R Yorke Worthington, Weenen”, Natal Agricultural Journal, January 1906, p. 223.

Quoted by Roux, Huisvriend, p. 80. See also Hopkins, Ned Geref Kerk Calitzdorp, p. 78.

Momberg, Regionale studie van die distrik Calitzdorp, p. 68.

Statistics provided by the South African Weather Service, Pretoria, 9 June 2015.

TD, 11(3), December 2015, pp. 186-207. 
1940 and 1974) of below-average runoff. ${ }^{27}$ Thus DF Kokot, chief engineer (planning) of the former Department of Irrigation by the mid-twentieth century, remarked that irrigation (e.g. in Calitzdorp) was necessitated by the inadequacy and uncertainty of the rainfall. ${ }^{28}$

\section{The establishment of the Calitzdorp Irrigation Board and the construction of the Calitzdorp Dam}

The first settlers who owned riparian properties along the banks of the Nels River utilized its waters for irrigation by constructing weirs of earth and stone, and even concrete, in order to divert floodwater onto their lands. ${ }^{29}$ The Cape Irrigation Act of 1906 was concerned mainly with defining and determining the exact nature of riparian rights as it consolidated the rules of regulating the use of streams. ${ }^{30}$ For instance, the deeds of transfer of several Calitzdorp farms were subject to certain servitudes. In dry seasons those farmers could irrigate their lands only for four consecutive days according to water use turns with their downstream neighbours. ${ }^{31}$

According to Ertsen, water development programmes in Africa included dams for electricity production and flood control, purification facilities for drinking water, the construction of piped supplies and extensive irrigation projects. Whether designed by engineers working for a colonial power or the post-colonial state, all of these projects sought to control the flow of water for the purpose of economic and agricultural development. ${ }^{32}$ The year 1912 signalled the beginning of large-scale state investment in water storage infrastructure and the start of South Africa's first dam-construction boom on a national scale. Molle, et al., argue that internationally by the beginning of the $20^{\text {th }}$ century there was a general craze for irrigation development. ${ }^{33}$ Indeed, during the first half of that century the South African irrigation authority concerned itself with the agricultural use of water. The Union Irrigation and Conservation of Water Act, No. 9, was promulgated in 1912, resulting in the creation of the Union Irrigation Department with FE Kanthack as its first director. The act provided the national law regulating the use of water in public streams. Special judicial machinery was created in the form of water courts for dealing with the definition of water-rights along public streams, the settlement of disputes, granting of servitudes and permits, the establishment of river and irrigation districts and boards, as well as the granting of loans to boards and individuals for the purposes of constructing irrigation works.

Le Maitre, et al., Water resources in the Klein Karoo, p. 42.

DF Kokot, Irrigation Department Memoir. An Investigation into the evidence bearing on recent climatic changes over Southern Africa, Government Printer, Pretoria, 1948, p. 42.

L van Vuuren, In the Footsteps of Giants - Exploring the history of South Africa's large dams, Water Research Commission of South Africa, Pretoria, 2012, p. 30; Momberg, Regionale studie van die distrik Calitzdorp, pp. 49-50; Hopkins, Ned Geref Kerk Calitzdorp, p. 129.

(3)

Colony of the Cape of Good Hope, Acts of Parliament. Session of 1906, being the third session of the eleventh parliament, Cape Times Limited, Cape Town, 1906, pp. 5138-5177; H Thompson, Water Law. A practical approach to resource management and the provision of services, Juta \& Co Ltd, Cape Town, 2006, p. 52.

Hopkins, Ned Geref Kerk Calitzdorp, p. 13.

W Ertsen, "Controlling the farmer: colonial and post-colonial irrigation interventions in Africa", The Journal for Transdisciplinary Research in Southern Africa, Vol. 4, No. 1, July 2008, p. 210.

Quoted by Musemwa, Water scarcity and the colonial state, p. 81. 
Importantly, the act underlined government policy to foster private and cooperative enterprise rather than to undertake extensive state schemes. It also confirmed the government's almost exclusive focus on water for agricultural use. Riparian owners (i.e. farmers) would be encouraged to establish an irrigation district under the 1912 act for the purpose of undertaking the scheme as a cooperative work financed under an irrigation loan. These loans were granted for up to thirty years and could only be obtained from the Irrigation Department. The objective of this act was the catalyst for much of the later irrigation development and agricultural prosperity in South Africa. ${ }^{34}$

During the 1890s the Member of Parliament for Oudtshoorn, Mr GC Olivier, began to lobby for the establishment of the Nels River irrigation scheme at Calitzdorp in order to protect the local fruit farms against possible water shortages. In 1893 the first trial pits were dug to test bedrock stability and water flow measurements were done for constructing a dam, but the local farmers were not prepared to pay more than $£ 210$ s per morgen for water tariffs. It was envisaged that the proposed dam would irrigate 1800 morgen (1540.80 ha) of which 1200 morgen (1027.20 ha) was earmarked for the Gamka plains south of the town. According to the draft bill it was estimated that the whole scheme would cost in the vicinity of $£ 50000$ which was apparently approved by the Cape Parliament. However, the outbreak of the Anglo Boer War in 1899 and the subsequent economic depression led to a postponement of the proposed project. By 1912 a petition was signed by BL Saayman and 67 other riparian farmers, requesting the Union Parliament to declare land along the Nels River as an irrigation district under the new act. On 11 June 1912 about sixty farmers met with $\mathrm{Mr}$ TE Scaife, the hydraulic circle engineer for the region, in the Coronation Hall in Calitzdorp, to discuss the issue.

According to a 1911 report by FE Kanthack, the director of the Irrigation Department, the proposed dam with two main canals, one on each side of the river, would bring about 700 morgen $(599.20 \mathrm{ha})$ under irrigation and also increase the existing water supply of the 450 morgen (385.20 ha) already under river irrigation. The Calitzdorp Irrigation Board (CIB) was finally proclaimed in August 1912. On 1 November 1912 the following persons were elected as the first members of the CIB: BL Saayman (chairperson), MJ Fouché, JJ Geyser, DJJ Nel, JS Olivier and JN Pretorius. The CIB thus became one of the first irrigation boards to be established under the new Irrigation Act of $1912 . .^{35}$ On 1 December 1912 CC Brink was appointed as the first CIB secretary at $£ 6$ per month. ${ }^{36}$

AW Carruthers, Official Year Book of the Union of South Africa and of Basutoland, Bechuanaland Protectorate, and Swaziland, No. 14, 1931-1932, The Government Printing and Stationery Office, Pretoria, 1933, p. 339; Van Vuuren, In the Footsteps of Giants, pp.66, 68; LD Hobbs and RF Phélines, Water 75, Erudita Publications (Pty) Ltd, Johannesburg, 1975, pp. 31,33, 39.

Archives of the Department of Water and Sanitation, Government Gazette, 19.11.1912, p. 1200 (Notice No. 1787 of 1912, Calitzdorp Irrigation Board, Cape); Archives of the Calitzdorp Irrigation Board (hereafter CIB), Minutes of Meeting held in the Court Room, Calitzdorp, 1.11.1912; Ibid., Notulen van eene Vergadering gehouden op den 29ste November 1912; Hopkins, Ned Geref Kerk Calitzdorp, p. 129; PA Taylor, "Calitzdorp Dam”, SA Irrigation Magazine, 15 September 1914, p. 156; Anon., "Calitzdorpdam - SA se eerste beton besproeiingsdam", The Civil Engineer in South Africa, Vol. 28. No. 11, November 1986, p. 449; FA Venter, Water, Afrikaanse Pers-Boekhandel, n.p., 1970, p. 313.

CIB, Notulen van eene vergadering gehouden op den 13de December 1912. 
1913 was an eventful year for Calitzdorp. Not only did the town receive full municipal status, but a suitable bedrock foundation was found at Besemkop, $4 \mathrm{~km}$ north of the town. Therefore the construction of the Nels River Dam, or Calitzdorp Dam as it is generally being referred to in the literature, commenced on 1 November 1913. Mr. RJ Garratt from Britstown was appointed as resident engineer at $£ 700$ per annum and the CIB applied for an initial government loan of $£ 65000$ to finance the building of the dam and the irrigation works. Construction hours on the dam site were from 6 am until $6 \mathrm{pm}$ on weekdays, with half an hour breakfast and an hour lunch break, and from 6am until $2 \mathrm{pm}$ on Saturdays but at times had to be altered as a result of the serious midday heat in summer. The dam was designed by the Union Irrigation Department and its features, such as the aesthetic arches and cornices, show a remarkable resemblance to the architectural design of the Kamanassie Dam east of Oudtshoorn, which was completed in $1923 .{ }^{37}$

Because of the First World War and the resultant economic depression which brought the collapse of the ostrich feather industry, many problems were experienced in the construction of the Nels River Dam. Cement deliveries were at times so infrequent as to cause serious delays. From 1915 onwards, the supplier of dam materials, Prince Vincent Co. of Oudtshoorn, could not obtain sufficient supplies of cement from abroad anymore and had to turn to Pretoria Portland Cement Co. Other construction material became more expensive than the original prices tendered for and construction wood became almost unattainable, which also caused construction delays. The water supply to the works was often precariously low. Faults were discovered in the foundation rock and the foundation excavation eventually cost far more than estimated. Consequently, the CIB was forced to apply for an additional government loan of $£ 25000$ and in September 1916 for another $£ 30000$. Another difficulty was the refusal of the Calitzdorp Divisional Council to take over the road deviation constructed by the CIB as a substitute for that portion of the Calitzdorp-Groenfontein road eventually submerged by the dam. This refusal created great inconvenience to construction methods, as the public road in use prior to being submerged, passed through the busiest spot on the construction works. ${ }^{38}$ At least a number of sub-contractors were contracted to transport supplies such as sand, stone and cement and the circulation of money due to the

37 CIB, Notulen van eene vergadering gehouden op 14 Februari 1913; Ibid., Notulen van eene buitengewone vergadering gehouden op 7 Augustus 1913; Ibid., Notulen eene speciale vergadering gehouden op 26 September 1913; Ibid., Notulen van eenen gewone vergadering gehouden op 13 October 1913; Ibid., Notulen van eene speciale vergadering gehouden op 4 November 1914; Taylor, “Calitzdorp Dam”, pp. 156, 160; Anon., "Calitzdorpdam”, p. 449; Hopkins, Ned Geref Kerk Calitzdorp, pp. 130, 135; Roux, Piet Strydom, p. 67; Roux, Huisvriend, p. 168; Venter, Water, p. 313. Hopkins, Ned Geref Kerk Calitzdorp, p. 132 and Roux, Huisvriend, p. 132 erroneously indicate the commencement of construction on the Nels River Dam as 1912. With regard to the construction of the Kamanassie Dam, see Van Vuuren, In the Footsteps of Giants, pp. 83-85; Venter, Water, pp. 315-316 and JM Jordaan (ed.), Large Dams and Water Systems in South Africa, SANCOLD, n.p., 1994, p.

CIB, Notulen van eene vergadering gehouden op 9 Februari 1914; Ibid., Notulen eenen vergadering gehouden op 10 Mei 1915; Ibid., Notulen van eene vergadering gehouden op 31 January 1916; Ibid., Notulen van eene buitengewone vergadering gehouden op 22 Februari 1916; Notulen eenen vergadering gehouden op 13 Maart 1916; Ibid., Notulen van eene vergadering gehouden op 11 September 1916; Ibid., Notulen eenen vergadering gehouden op 13 November 1916; Western Cape Archives and Records Service (hereafter WCARS), Archives of the Provincial Administration (hereafter PAS), Vol. No.4/439, Ref. A10; Taylor, “Calitzdorp Dam”, p. 160. 
dam construction contributed to alleviate the dire socio-economic circumstances which had developed in Calitzdorp as a result of the prevailing economic depression. ${ }^{39}$

The Calitzdorp Dam was completed in 1918 and overflowed for the first time on 19 March 1922. The dam is constructed as a mass concrete gravity wall containing about $110000 \mathrm{~m}^{3}$ tons of concrete. Its maximum thickness at the bottom is $22.6 \mathrm{~m}$ and its top thickness is 2.5 $\mathrm{m}$. The length of the wall is $213 \mathrm{~m}$ and its height $34.1 \mathrm{~m}$. At full supply the capacity of the dam is 5.9 million $\mathrm{m}^{3}$ and covers a surface of 58 ha while its catchment converge a surface area of $170 \mathrm{~km}^{2}$. According to various sources, the still operational Calitzdorp Dam was the first, and therefore oldest mass concrete storage dam in South Africa built for irrigation purposes. ${ }^{40}$ Although construction was successful, financially it was a gross miscalculation. The final costs soared from the initial estimate of $£ 65000$ to $£ 168053$ eventually, which was way above the CIB's financial ability to repay; this compelled the government to reduce the repayment and interest rates. ${ }^{41}$ In 1934 the Minister for Agriculture and Forestry apparently put the irrigation scheme under the administrative control of a Select Committee on Irrigation Matters for some time. ${ }^{42}$

\section{The CIB and the provision of water to the Calitzdorp Municipality to c. 1950}

Since the town's founding, the source of Calitzdorp's drinking water had been a furrow diverted from the Nels River, and rain water was also harvested through sink or cement tanks. ${ }^{43}$ And as early as 1908 the Village Management Board declared "that a serious and dangerous pollution of the water in the Nels River takes place", e.g. as a result of night soil pits and closets being erected too close to the river. The washing of clothes in the river also contributed to the pollution problem. ${ }^{44}$ In addition, the unhealthy situation of an open furrow

Taylor, "Calitzdorp Dam", p. 163; Roux, Piet Strydom, pp. 67, 69; CIB, Notulen van eene vergadering gehouden op 10 Juli 1916.

Taylor, "Calitzdorp Dam”, pp.155-156, 158; Anon., "Calitzdorpdam”, pp. 449, 452; Venter, Water, p. 313; Roux, Piet Strydom, p. 82; Roux, Huisvriend, p. 180. Although other similar dams were built before the Calitzdorp Dam such as the Woodhead Dam (1897) and the Hely-Hutchinson Dam (1904) on Table Mountain, Sand River Dam (1905), the Bulk River Dam (1907), the Bongolo Dam (1908) near Queenstown and the Hell's Gate Dam (1910) near Uitenhage, they were either reservoirs for drinking water or stone masonry dams. See Jordaan, Large Dams and Water Systems, pp. 128-129, 220, 234 and Van Vuuren, In the Footsteps of Giants, pp. 48, 51-54, 59-60; Hobbs and Phélines, Water 75, p. 201 and Communiqué from L van Vuuren, 18.6. 2015.

Union of South Africa, S.C. 3a-'34, Second Report of the Select Committee on Irrigation Matters, Cape Times Limited, Cape Town, 21 May 1914, pp. 8-9; Unie van Suid-Afrika, S.C. 3 - '35, Verslag van die Gekose Komitee oor Besproeiingsake, Cape Times Beperk, Kaapstad, 28 Maart 1935, p. xxxvi; CDH Braine, "Irrigation Problems in South Africa. The case for small schemes", The Sun E Agricultural Journal of $S A$, August 1914, p. 53; Taylor, "Calitzdorp Dam", p. 164; Hopkins, Ned Geref Kerk Calitzdorp, pp. 130-131; Roux, Piet Strydom, p. 84. See also WCARS, Archives of the Calitzdorp Divisional Council (hereafter 3 or 4/CDP), 3/CDP, Vol. No. 1/1/1/1, Spesiale vergadering gehou op 2 Februarie 1934, p. 249.

See CIB, Notule van vergadering gehou op 8 Desember 1934; Ibid., Notule van die eerste vergadering van die Raad gehou op die 18de Desember 1934.

WCARS, PAS, Vol. No. 2/319, Ref. L73C, Correspondence: Medical Officer of Health - Village Management Board Calitzdorp, April 1908; Ibid., PAS, Vol. No.2/319, Ref. L73A, Memorandum: Medical Officer of Health, 15 June 1908; Ibid., 3/CDP, Vol. No. 1/1/1/1, Notulen eenen vergadering gehouden c. Mei 1913, p. 190. 
conveying water for domestic purposes to the town of Calitzdorp was prone to harmful organisms causing periodical epidemics such as enteric and typhoid fever within the municipal boundaries from 1915 onwards. ${ }^{45}$

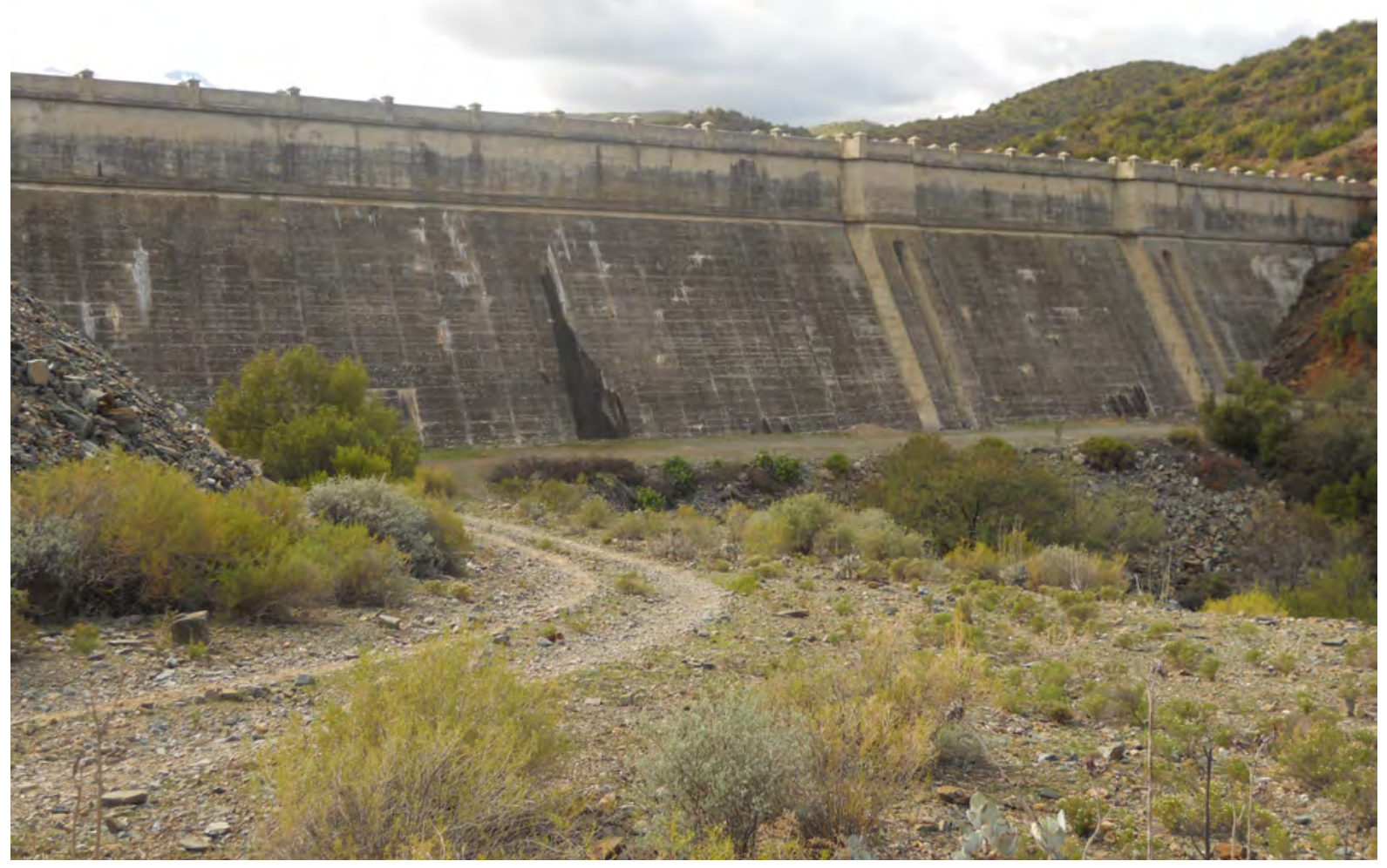

Illustration 2 The dam wall stabilised in 1991 (Source: Author's private collection)

Not surprisingly, therefore, the town clerk of the Calitzdorp Municipality approached the CIB about the possibility of providing water from the dam to the town in January 1914 already, in order to improve the undesirable water supply system. ${ }^{46}$ In May 1915 the CIB secretary inquired from the Director of Irrigation whether the board was warranted to provide water for domestic purposes from the irrigation scheme to the municipality. The CIB farmers also had be consulted about the municipal request. ${ }^{47}$ The CIB agreed and was prepared to act as a water company to provide water to municipality at an average of 45000 gallons (204545.45 litre) per day at 6d per 1000 gallons (4545.45 litre), but made it clear that

45 See WCARS, 3/CDP, Vo. No. 1/1/1/2, Notulen van een vergadering gehouden op 4 April 1918; Ibid., WAD, Vol. 617, No. 925/MI, Correspondence: E Fincham - Director of Irrigation, 4 September 1929, pp. 2, 7-8, 18; Ibid., PAS, Vol. No. 2/473, Correspondence: HH Hudson - Assistant Medical Officer of Health, 30 January 1915, pp. 1-3; Ibid., PAS, Vol. No. 2/473, Correspondence: Acting Secretary for the Interior - Provincial Secretary, 16 February 1916; Ibid., PAS, Vol. No. 2/473, Correspondence: Provincial Secretary - Calitzdorp Mayor, c. March 1915.

CIB, Notulen eenen vergadering gehouden op 19 Januari 1914; Ibid., Notulen eenen vergadering gehouden op 14 Juni 1915; WCARS, PAS, Vol. No. 2/473, Correspondence: JWK Maree - Secretary CIB, 27 April 1915; Ibid., 3/CDP, Vol. No. 1/1/1/1, Speciale vergadering gehouden op 17 April 1915 , p. 331.

47 CIB, Notulen van eene buitengewone vergadering gehouden op 17 Mei 1915. 
water would only be provided if available. These resolutions were also approved by the Irrigation Department, although Kanthack, the Director of Irrigation, explained that under the provisions of the 1912 Irrigation Act the CIB could not serve as a water company and undertook the construction of a water reticulation system on behalf of the municipality. ${ }^{48}$

However, a long and unsavoury dispute developed between the CIB and the Calitzdorp Municipality over the water tariffs to be paid by the latter. The municipality maintained that it was also riparian to the Nels River. It was argued that the owners of the farm Buffelsvlei (on which the town of Calitzdorp was established), and therefore also the municipal council, were entitled to "the normal flow" of the Nels River. According to the council the CIB had no right to sell water to the municipality but the latter would be prepared to pay for the storage costs of its portion of Nels River water in the Calitzdorp Dam. Based on its own calculations the council was prepared to pay $2 \mathrm{~d}$ per 1000 gallons (4545.45 litre) of water. ${ }^{49}$ By March 1918 the dispute seemed to have been stalled into a deadlock between the two parties concerned and in correspondence between government officials arbitration on the matter was suggested..$^{50}$ By 1920 the municipality considered purchasing the uppermost portion of the farm Matjiesgoedvlei. The farm was situated on the Smits River, a tributary of the Nels River north of the Calitzdorp Dam. It was entitled to a scheduled turn of 69 hours every fourteen days of access to water in the full stream. ${ }^{51}$ The matter was still pending by 1929 . Although the municipality was of the opinion that by obtaining riparian rights in the Smits River it could "strengthen [its] position in any negotiations with the Irrigation Board with regard to the storage of water in the Calitzdorp Dam", government officials doubted whether it would be legal under the 1912 Irrigation Act. $^{52}$

Unfortunately the CIB minute books for the period 1917-1932, as well as other relevant municipal documents, seem to have been lost, rendering it impossible to ascertain the outcome of the CIB-Calitzdorp Municipality water dispute of that period. According to Roux the municipality's drinking water furrow, which diverted water from the Nels River below the dam, existed until 1935. In that year the CIB decided to allocate 100000 free gallons $\left(455 \mathrm{~m}^{3}\right)$ of water per day from the dam to the municipality for domestic purposes, subject to approval by the Director of Irrigation. Again it was clearly stipulated that the

Ibid., Notulen eenen speciale vergadering gehouden op 17 Mei 1916; Ibid., Notulen van eene vergadering gehouden op 10 Juli 1916; WCARS, 3/CDP, Vol. No. 1/1/1/1, Notule van gewone maandelikse vergadering op 4 Augustus 1916, pp. 370-371; Ibid., Archives of the Water Affairs Department (hereafter WAD), Vol. 617, No. 925/MI, Correspondence: Circle engineer - Local Government Inspector, 22 August 1929, p. 4; Ibid., WAD, Vol. 617, No. 925/MI, Correspondence: E Fincham - Director of Irrigation, 4 September 1929, p. 18.

WCARS, PAS, Vol. No. 2/473, Correspondence: Town Clerk - Chief Local Government Inspector, 26 October 1917.

Ibid., PAS, Vol. No. 2/473, Correspondence: Magistrate -Chief Local Government Inspector, 13 March 1918.

Ibid., PAS, Vol. No. 2/473, Correspondence: Town Clerk - Chief Local Government Inspector, 16 February 1920.

WCARS, PAS, Vol. No. 2/473, Correspondence: Town Clerk - Provincial Secretary, 23 April 1915; Ibid., PAS, Vol. No. 2/473, Unidentified handwritten memo, Calitzdorp Municipality purchase farm Matjiesgoedvlei water supply, 28 April 1925; Ibid., WAD, Vol. 617, No. 925/MI, Correspondence: Circle engineer - Local Government Inspector, 22 August 1929, p. 3; Ibid., Correspondence E Fincham - Director of Irrigation, 4 September 1929, p. 18. 
municipal water allocation should under no circumstances interrupt any turn to use water by the board's irrigators. ${ }^{53}$ In 1937 the firm of CB Uys from Heidelberg, Cape Province, installed a water scheme for Calitzdorp to the amount of $£ 8000 .{ }^{54}$ However, even the new scheme to the town was not without problems. Until 1992 the municipality's water allocation was channelled rather ineffectively through an open furrow which was partly cemented and partly earthen, to a purification plant. This practice caused water losses of up to $30 \%$ per month and the municipality decided to replace it with piped water distribution between the dam and the municipal purification plant. ${ }^{55}$

During the drought periods of 1923-1927 and 1946-1947 the Calitzdorp Dam was almost empty with no water available for irrigation ${ }^{56}$ and which would also have a detrimental effect on the town's water supply. This illustrates how dependent the municipality had become of CIB water since the board had consented to allocate a water quota to the town for domestic use. In 1924, with less than $3.716 \mathrm{~m}$ of water in the dam, the newly-constructed railway line from Oudtshoorn also served Calitzdorp as a water lifeline when tanks with water were supplied gratis from the neighbouring town. ${ }^{57}$ The Oudtshoorn Municipality also supplied Calitzdorp with free water in December 1927 because the water quality from the dam was very poor. ${ }^{58}$ Municipal water restrictions were imposed during the drought period of 1942 and $1943 .{ }^{59}$ And during the serious drought of 1945-1947 the situation became critical again. In 1946 the Calitzdorp Dam was virtually empty again and placards were put up in town urging people to conserve water. The Medical Officer of Health requested that the CIB should not allocate water turns for the municipal quota below a level of $2.323 \mathrm{~m}$ in the dam as it would release foul water for domestic use. ${ }^{60}$ In 1947 the municipality declared a water emergency and it was decreed that all municipal water was to be used for household purposes only. Pits were dug in the bed of the Nels River below the dam, in efforts to obtain water usable by animals while the municipality also considered acquiring a chloride gas device for water purification. ${ }^{6}$

Another water contestation between the CIB and the Calitzdorp Municipality seems to have arisen in the aftermath of the 1945-1947 drought. The municipality obtained an advocate's

Roux, Huisvriend, p. 188; Hopkins, Ned Geref Kerk Calitzdorp, p. 131; CIB, Notule van 'n gewone vergadering gehou 12 November 1935.

Momberg, Regionale studie van die distrik Calitzdorp, p. 90; Hopkins, Ned Geref Kerk Calitzdorp, pp. 135-136; Roux, Piet Strydom, p. 76; Roux, Huisvriend, p. 188. See also WCARS, 3/CDP, Vol. No. 1/1/1/1, Notule van 'n belastingbetalersvergadering gehou op 11 Februarie 1936, p. 322; Ibid., Notule van 'n spesiale vergadering gehou op 4 Augustus 1936, pp. 333, 349.

CIB, Correspondence: Stadsklerk - Sekretaris Calitzdorp Besproeiingsraad, 7 Julie 1992.

Momberg, Regionale studie van die distrik Calitzdorp, p. 53.

Roux, Piet Strydom, pp. 82, 86.

WCARS, 3CDP/1/1/1/3, Gewone vergadering gehou op 1 Maart 1928, p. 64; Ibid., Spesiale vergadering gehou op 31 Desember 1927, p. 56.

Ibid., 3/CDP), Vol. No. 1/1/1/4, Gewone vergadering gehou op 20 Augustus 1942; Ibid., 3/CPD, Vol. No. 1/1/1/4, Gewone vergadering gehou op 18 November 1943.

Ibid., 3/CDP, Vol. No. 1/1/1/4, Gewone vergadering gehou op 21 Februarie 1946; Ibid., 3/CDP, Vol. No. 1/1/1/4, Spesiale vergadering gehou op 12 Desember 1946.

Ibid., 3/CDP, 1/1/1/4, Gewone vergadering gehou op 20 Februarie 1947. 
opinion as to the town's riparian rights to extract water from the Nels River above the Calitzdorp Dam. This would have been in the river's catchment area that fell under the servitude and control of the CIB. ${ }^{62}$

\section{Increasing pressure on the CIB for municipal water provision, c. 1950 - 1994}

Drought conditions and water shortages, also due to further municipal needs, were main determinants in relations between the CIB and the municipality between the 1950s and the early 1990s. In 1952 the municipality requested the CIB for a bigger water allocation to irrigate its sports fields but this was denied..$^{63}$ Some impatience from the board becomes apparent in 1955 when through negligence municipal water officials did not close the sluices to the municipal reservoir during its water turn to prevent water spillage. ${ }^{64}$ But in 1960 the municipality inaugurated the town's public swimming pool which would use 4000 gallons (18 181.82 litre) of water monthly from the domestic water allocation. In the same year, however, drought conditions prevailed and strict water restrictions had to be imposed ${ }^{65}$

Another drought period hit the Little Karoo in 1966-1967 which forced the municipality to introduce water restrictions. ${ }^{66}$ The CIB minutes refer to the municipality approaching the board with regard to a "gentleman's agreement" regarding water usage for domestic purposes, which was probably a request for more leniency in terms of the municipal water allocation. But once again this request was turned down because the CIB was also imposing water restrictions on agricultural irrigators since September 1966. ${ }^{67}$ Indeed, on 22 December the board declared an emergency in terms of water turns. ${ }^{68}$

A very serious drought returned to Calitzdorp in 1970 and the CIB minutes refer to the "desperate" drought conditions of the "most serious drought in living memory" which was of deep concern to the irrigation farmers. According to the circle engineer of the Department of Water Affairs (as the former Irrigation Department was renamed in 1956) the remaining water in the dam was "in a state of neglect". The Calitzdorp Farmer's Association wrote to the MP for Oudtshoorn to obtain a government loan of R10 000 to cement the walls of more stretches of its canals, which would save more than $30 \%$ of the water that was oozing away through earthen furrows. ${ }^{69}$ In conjunction with these water saving measures the CIB proposed that the Calitzdorp Municipality apply for a loan from the Western Cape

WCARS, 3/CDP, Vol. No. 1/1/1/4, Gewone vergadering gehou op 20 Maart 1947; Ibid., 3/CDP, Vol. No. 1/1/1/4, Gewone vergadering gehou op 17 Maart 1948. The outcome of the advocate's opinion could not be obtained in the archives.

CIB, Notule van 'n gewone vergadering gehou op 12 Augustus 1952.

Ibid., Notule van 'n gewone vergadering gehou op 13 September 1955.

Roux, Huisvriend, pp. 258, 264-268, 282.

Ibid., p. 284.

CIB, Notule van 'n gewone vergadering gehou op 6 Desember 1966.

Ibid., Notule van 'n spesiale vergadering gehou op 22 Desember 1966.

Ibid., Corresondence: Calitzdorp Boerevereniging - PMK le Roux, 17 Augustus 1970; Ibid., Notule van 'n gewone vergadering gehou op 2 Maart 1971.

TD, 11(3), December 2015, pp. 186-207. 
Provincial Administration to lay a pipeline between the dam and the town's water purification works. ${ }^{70}$

After the dry spell of 1974 consulting engineers submitted the following report to the town clerk with regard to the municipal water scheme: Although it was entitled to $455 \mathrm{~m}^{3}$ of water the municipality utilised $365 \mathrm{~m}^{3}$ during that summer. As a result, the Calitzdorp Dam's water supply almost dried up, therefore the municipality was forced to impose water restrictions. It was expected in any case that peak municipal water use would exceed the maximum of 455 $\mathrm{m}^{3}$. It became imperative that the water supply should be improved. The most important recommendation therefore was that all water turns of domestic water for the irrigation of town gardens as a portion of the municipality's $455 \mathrm{~m}^{3}$ water allocation be terminated. This would be the most economic water saving measure. ${ }^{71}$ In November 1975 the municipality approached the $\mathrm{CIB}$ with another request to increase its $455 \mathrm{~m}^{3}$ daily water allocation, which was refused. ${ }^{72}$ Although several meetings were held between the Calitzdorp Municipality and the CIB regarding the agreed upon daily water allocation no satisfactorily arrangement could be reached. During the 1970s it became clear that the municipal water demand increased steadily and that its quota was exceeded on almost a daily basis. Relations between the two authorities became strained over the issue and the CIB contemplated legal advice and even consulting the Department of Water Affairs with regard to the continuous over-use of the municipal water quota. ${ }^{73}$ For example, where the average monthly supply of water to the municipality amounted to 25 hours in March 1953, it had increased to 54 hours by April $1978 .{ }^{74}$

Some reasons remained for Calitzdorp's increasing domestic water needs. Since 1978 the CIB became aware of plans by the Department of Community Development to build new homes and extend the Coloured township of Calitzdorp for which no extra provision had been made for water supply. ${ }^{75}$ The town's Coloured community grew from 1050 in 1951 to 2140 by 1980 - an increase of almost 100\%. The daily municipal water use by 1980 was 509 $\mathrm{m}^{3}$ which exceeded its allocation from the CIB by $11 \%$. At peak periods during summer the daily water use was even as high as $727 \mathrm{~m}^{3}$. And since the 1920 s five fruit processing plants, four wine-cellars and two fresh food packing stores were established in town, adding pressure on the available potable water supply. 70 new homes were built in the Coloured township

Ibid., Correspondence: Voorsitter Calitzdorp Besproeiingsraad - Streeksingenieur Dept. van Waterwese, 1 Oktober 1973.

Ibid., Correspondence: Ninham Shand en Vennote - Stadsklerk Calitzdorp, 25 Maart 1975. See also Roux, Huisvriend, p. 292.

CIB, Notule van 'n gewone vergadering gehou op 4 November 1975. See also Ibid., Notule van 'n gewone vergadering gehou op 3 Februarie 1976.

See e.g. Ibid., Notule van 'n gewone vergadering gehou op 27 Julie 1976; Ibid., Notule van 'n gewone vergadering gehou op 14 Januarie 1977; Ibid., Notule van 'n gewone vergadering gehou op 2 Februarie 1978; Ibid., Notule van ' $n$ gewone vergadering gehou op 4 April 1978; Ibid., Notule van 'n gewone vergadering gehou op 2 Mei 1978; Ibid., Notule van 'n spesiale vergadering gehou op 16 Junie 1978.

Ibid., Notule van 'n gewone vergadering gehou op 10 Maart 1953 and Ibid., Notule van 'n gewone vergadering gehou op 4 April 1978.

Ibid., Notule van 'n gewone vergadering gehou op 7 Februarie 1978; Ibid., Notule van 'n gewone vergadering gehou op 7 November 1978; Ibid., Notule van 'n spesiale vergadering gehou op 5 Desember 1978. 
since the 1980s and the municipality made 50 new plots available for white dwellings. Because of a lack of adequate water supply to meet these increasing demands 150 ha of irrigation land could not be utilised. ${ }^{76}$ Another problem was that silt deposits were also beginning to diminish the Calitzdorp Dam's capacity. ${ }^{77}$

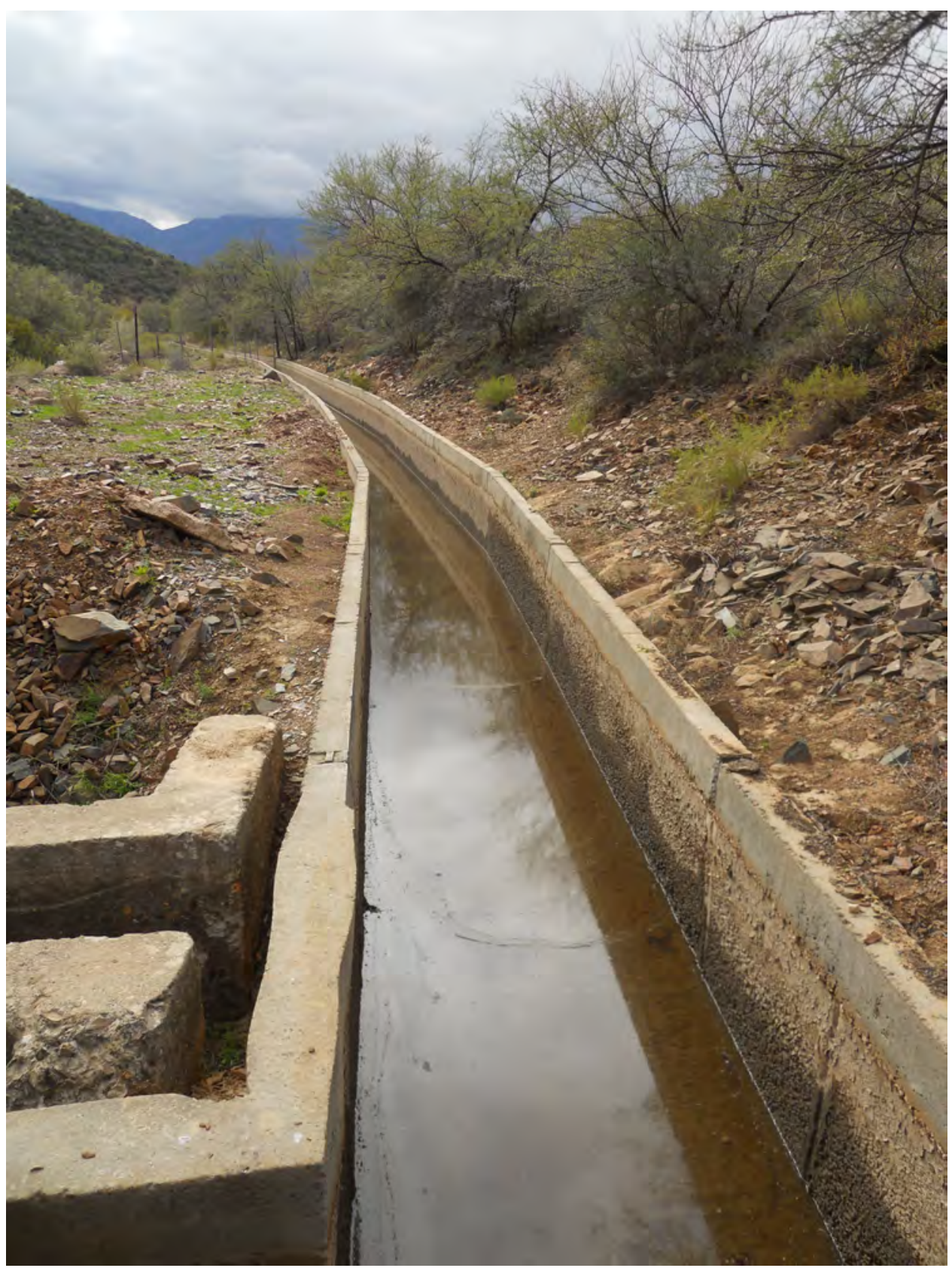

Illustration 3 Section of the cemented canal $1 \mathrm{~km}$ from the dam wall (Source: Author's private collection)

76 CIB, Memorandum ter aanvulling van mondelingse besprekings met sy edele, SAS Hayward, Minister van Omgewingsake en Visserye, 18 Junie 1984; Ibid., Correspondence: Sekretaris Calitzdorp Besproeiingsraad - Direkteur-Generaal Departement van Waterwese, 27 Januarie 1986.

77 Ibid., Notule van 'n spesiale vergadering gehou op 22 Oktober 1980; Ibid., Correspondence: Sekretaris Calitzdorp Besproeiingsraad - Seksie-ingenieur Departement Omgewingsake, 15 November 1982.

TD, 11(3), December 2015, pp. 186-207. 
In the light of the town's growing population, coupled with the increasing water needs and the board's constant struggle to meet these demands, especially during the summer months, as well as recurring droughts which made the agricultural and economic position of its irrigators extremely vulnerable, the CIB began to consider alternative measures to augment its limited water supply. ${ }^{78}$ Apart from the above-mentioned 1973 proposal that a municipal pipeline should be laid between the dam and the town's water purification works to maximise efficient water delivery and minimise wastage, the CIB discussed as early as 1959 the possibility of raising the Calitzdorp Dam's spillway to counter the silt deposits. ${ }^{79}$ Alternatively, if the cost of raising the spillway would be too high, the possibility of constructing a second dam in the Nels River south of the Calitzdorp Dam was to be considered. ${ }^{80} \mathrm{~A}$ third option was to upgrade the CIB's ageing canal system to the amount of R101 600 (1975 estimates) which should save water and minimise water losses. ${ }^{81}$

The question of upgrading the wall of the Calitzdorp Dam was expedited in correspondence between the Department of Environment Affairs (responsible for dam safety), the Department of Water Affairs and the CIB. The dam's 1912 design failed to meet modern design criteria and would probably not withstand a hundred year flood. Should the wall yield under the pressure of such a flood the consequences would imply a possible loss of life. It would also be an economic disaster for Calitzdorp because agriculture and related industries provided employment to more than $90 \%$ of the community. Not only was the dam the only source of water for the local municipality but a disastrous flood would displace the community which would have to be resettled elsewhere. Flood damage claims against the CIB could be as high as R24 million. It was therefore imperative that the structural integrity of the dam wall be stabilised and secured. If the dam wall or spillway could be raised simultaneously, a larger water supply could be ensured, also for future needs, and if the unutilised 150 ha irrigation land could be cultivated through the use of water additional job opportunities would be created. ${ }^{82}$

However, the CIB's hopes for increasing the Calitzdorp Dam's capacity, subsidised by the Department of Water Affairs, were soon dashed. The department would stabilise the wall and improve the dam's spillway to deal with abnormal floods but to raise the wall would also entail a structural strengthening at high costs. The CIB already utilised more than $60 \%$ of the Nels River's annual run-off. Any economic benefits to be gained by raising the dam wall would be minimal in relation to costs of doing so. The estimates for raising the dam wall by 4 m was R20 million (1990 figures) which would cost R18.7 million more than securing it. Only $0.5 \mathrm{~m}^{3}$ or $12 \%$ more water would be harnessed annually. In the light of these calculations Water Affairs could not justify such a huge expenditure because the cost of

Ibid., Notule van 'n gewone vergadering gehou op 7 Oktober 1980.

Ibid., Notule van 'n gewone vergadering gehou op 30 Julie 1959.

Ibid., Correspondence: Voorsitter Calitzdorp Besproeiingsraad - Streeksingenieur Departement van Waterwese, 1 Oktober 1973; Ibid., Notule van 'n spesiale vergadering gehou op 22 Oktober 1980.

Ibid., RT Hooper, "Voorlopige Verslag van voorgestelde verbeterings an die voorstelsels van die Calitzdorp Besproeiingsraad”, 18 Februarie 1975.

Ibid., Correspondence: Direkteur-Generaal Departement van Waterwese - Sekretaris Calitzdorp Besproeiingsraad, 11 Mei 1984; Ibid., Correspondence: Sekretaris Calitzdorp Besproeiingsraad Direkteur-Generaal Departement van Waterwese, 27 Januarie 1986; Calitzdorp Museum Archives, Newspaper clipping: Oudtshoorn Courant, 29.6.1984 (Damwal kan breek, hoor Minister). 
irrigation water would become ten times higher than any agricultural gains to be made from it. It was also clear that the CIB would not be able to carry the costs of raising the dam wall. Therefore Water Affairs saw its way open to ensure its integrity on state costs by increasing only the spillway. ${ }^{83}$

The Department of Water Affairs' resolve did not solve the CIB's water predicament. The CIB complained that in the period 1984-1990 the Calitzdorp Municipality exceeded its water allocation on average by $117.270 \mathrm{~m}^{3}$ which put extra pressure on the board's irrigators. The department acknowledged that Calitzdorp, as elsewhere in the Little Karoo, had excellent irrigation land available but not enough water. However, Water Affairs somewhat annoyingly made it clear that the CIB had been bickering fruitlessly for more than 40 years about improving the canal system below the dam to diminish water losses, without actually resolving the issue. The state had long since withdrawn from involvement in such work and the whole enterprise had to be planned, designed and executed by the board through a government subsidy. ${ }^{84}$ By May 1991 the department's construction activities to improve the security of the Calitzdorp Dam had been completed. ${ }^{85}$

In the meantime the 1975 estimates of R101 600 to upgrade the CIB canal system had risen to R1.5 million by 1992. Perusal of the available archival documents reveals that there was doubt whether the CIB's irrigators would be able to pay the increased water tariffs to finance such a loan and whether an upgraded system would actually realise the availability of $25 \%$ more water. A loan to the amount of R1.5 million was secured from the Land Bank in 1992 but by 1997 the board struggled indeed to pay back the bonds. ${ }^{86}$

After a period of fairly abrasive correspondence between the CIB and the Calitzdorp Municipality regarding outstanding payments for exceeding its water allocation since 1990, an amicable settlement was reached between the two entities by 1992 regarding the municipal water supply. As explained earlier, a $150 \mathrm{~mm}$ municipal pipeline was constructed between the dam and the town's purifications works to replace the ineffective open furrow which caused water losses of up to $30 \%$ per month. Thus, it became unnecessary to restrict municipal water according to turns of access to water as all water obtained from the Calitzdorp Dam would be checked by meters. ${ }^{87}$ However, the pipeline did not end the municipality's exceeding its water allocation..$^{88}$

CIB, Correspondence: Direkteur-Generaal Departement van Waterwese - Voorsitter Calitzdorp Besproeiingsraad, 15 Mei 1990.

Ibid., Correspondence: Calitzdorp Beproeiingsraad - Stadsklerk Calitzdorp Munisipaliteit, c. 1990; Ibid., Correspondence: JG Geyser - Streeksdirekteur Departement van Waterwese, 4 Julie 1990; Ibid., Corrrespondence: Streeksdirekteur Departement van Waterwese - Voorsitter Calitzdorp Besproeiingsraad, 19 Julie 1990.

Ibid., Correspondence: Direkteur-Generaal Waterwese and Bosbou - Voorsitter Calitzdorp Besproeiingsraad, 28 Mei 1991.

See Ibid., Notule van ' $n$ algemene vergadering gehou op 16 Maart 1992; Ibid., Notule van 'n spesiale vergadering gehou op 16 Maart 1992; Ibid., Correspondence: Streekdirekteur Departement van Waterwese - Voorsitter BAK, 26 Maart 1991, pp. 1-7; Ibid., Notule van 'n spesiale vergadering gehou op 21 Oktober 1992; Ibid., Notule van die jaarvergadering gehou op 3 Maart 1997; Ibid., Notule van die jaarvergadering gehou op 19 November 1998.

Ibid., Notule van 'n maandvergadering gehou op 7 Julie 1992; Ibid., Correspondence: Stadsklerk Calitzdorp Munisipaliteit - Sekretaris Calitzdorp Besproeiingsraad, 7 Julie 1992; Ibid., TD, 11(3), December 2015, pp. 186-207. 


\section{Changed relations: the CIB and municipal liaisons in the post-apartheid era}

The year 1994 brought an end to discriminatory practices and white rule in South Africa which would profoundly affect local governance as well. Henceforth local government representation and municipal councils would be multi-racial. But local government reforms had mixed successes. Service delivery deteriorated on a large scale and many smaller rural town councils began to face bankruptcy. ${ }^{89}$ These developments would also imply a change in the relationship between die CIB and local government in Calitzdorp. Although this relationship had been abrasive at times up to 1994, issues regarding municipal water allocation and usage and payment of water tariffs had usually been settled in a practical way and to mutual agreement. The interests of the all-white CIB and town council were intertwined in a community whose existence depended on agricultural economy supported predominantly by irrigation. As a rule many CIB members actually stay in the town, and were at times simultaneously members of the municipal council as well, and were also dependent on the municipal water provided by their own board. ${ }^{90}$ Thus, with regard to the municipal water allocation Mr JM Geyser, a former CIB chairperson, stated in 1993 that people were entitled to water first, then irrigators. ${ }^{91}$

However, due to the administrative problems experienced by rural town councils in particular, new district municipalities and municipal boundaries were demarcated through the Local Government Transition Act, No. 209 of 1993 and the Local Government Municipal Demarcation Act of $1998 .^{92}$ After the municipal elections of 2000, 843 municipal councils were replaced by 6 metropolitan, 241 local and 52 district councils. ${ }^{93}$ The Calitzdorp Municipality was dissolved after 88 years and all executive and administrative municipal powers shifted to Ladismith. This town is situated $50 \mathrm{~km}$ west of Calitzdorp and became the seat of the new Kannaland District Municipality under which Calitzdorp would resort henceforth. However, since its inception the Kannaland District Municipality was marred by political instability. A succession of single political party and coalition rule, which involved the Democratic Alliance, the African National Congress (ANC) and the Independent Civic Organisation of South Africa, led to inefficient administration and even corruption charges. ${ }^{94}$

Correspondence: Sekretaris Calitzdorp Besproeiingsraad - Stadsklerk Calitzdorp Munisipaliteit, 8 Julie 1992; Ibid., Memorandum van 'n ooreenkoms, 3 September 1992.

See e.g. CIB, Notule van 'n gewone vergadering gehou op 1 Junie 1993.

F Pretorius (red.), Geskiedenis van Suid-Afrika. Van voortye tot vandag, Tafelberg, Kaapstad, 2012, p. 566. See also Roux, Huisvriend, pp. 264, 268.

Private interview: J Fourie, chairperson CIB - W Visser, 30 October 2013. See also WCARS, WAD, Vol. 617, No. 925/MI, Correspondence: E Fincham - Director of Irrigation, 4 September 1929, pp. 18-19; Ibid., PAS. Vol No. 2/473, Correspondence: FE Kanthack - Provincial Secretary, 14 July 1915; Ibid., PAS, Vol. 2/473, Correspondence: JWK Maree - Provincial Secretary, 28 July 1915.

CIB, Notule van 'n gewone vergadering gehou op 1 Junie 1993.

Information provided by Dr D Brand, Extraordinary Senior Lector, School for Public Leadership, University of Stellenbosch, 24 June 2015.

Pretorius, Geskiedenis van Suid-Afrika, p. 566.

See Roux, Huisvriend, p. 378 and https://wikipedia.org/wiki/Kannaland_Local_Municipality [Accessed on 24.6.2015]. 
These changes had a profound impact on the community of Calitzdorp and the CIB. Way back in April 1985 already the CIB informed the then Calitzdorp Municipality that its supply would be cut off unless the water account were settled. ${ }^{95}$ This threat was reiterated in 2006. ${ }^{96}$ A greater demand for CIB water was also created when the national ANC government erected new homes for the Coloured community of Calitzdorp according to its Reconstruction and Development Programme. However, these homes were built between 1994 and 1997 without doing a proper environmental impact assessment or consulting with the CIB about the availability of water supplies. The municipal pipeline between the Calitzdorp Dam and the town continued to be problematic after 1994 despite meter monitoring. Although $1000 \mathrm{Kl}$ may be measured at the dam at times, only $900 \mathrm{~K} 1$ reach the municipal purification works due to pipe leakages which could be ascribed to lack of proper maintenance. ${ }^{97}$ At present, because of inefficient administration in the Kannaland Municipality and its poor communication to the CIB, water bills are being paid erratically to the board..$^{9} \mathrm{~A}$ lack of mutual trust and understanding developed and relations between the two institutions became even more strained. Because of the lack of any institutional knowledge about the history of the CIB and the historical water agreements between the board and the former Calitzdorp Municipality, Kannaland Municipality officials began to question the validity of these arrangements. Since 2013 the two institutions began to communicate to one another through their respective attorneys, while the Kannaland Municipality began to refuse to pay for irrigation-water from the Calitzdorp Dam. ${ }^{99}$

\section{Conclusion}

According to Franco, et al., land and water are interconnected. In many parts of sub-Saharan Africa, such as the Little Karoo, rainfall is too erratic for high investment in agricultural production without securing access to reliable water. ${ }^{100}$ The existence of Calitzdorp and its agricultural district was always determined by the availability of water or the lack thereof and its vulnerability to recurring droughts - a salient feature of the region. The CIB and the Calitzdorp Dam played a pivotal part in the town and the agricultural community's survival and economic development. Until the end of apartheid the CIB was the sole controller of water distribution from the Calitzdorp Dam. Legally the dam is in the unique situation of being one of probably only a few of its kind in South Africa. It belongs entirely to the scheduled farmers of the $\mathrm{CIB}$, the latter also being a corporate body. In addition, some

95 CIB, Notule van 'n gewone vergadering gehou op 18 April 1995; Ibid., Correspondence: Sekretaris Calitzdorp Besproeiingsraad - Hoof Uitvoerende Beampte Calitzdorp Munisipaliteit, 26 April 1995.

${ }^{96}$ Ibid., Notule van 'n gewone vergadering gehou op 9 Maart 2006.

${ }^{97}$ See Ibid., Notule van 'n gewone vergadering gehou op 25 Mei 1994; Ibid., Notule van 'n gewone vergadering gehou op 21 Junie 1995; Ibid., Correspondence: JO Fourie - M Hoogbaard, 28 November 2012; Roux, Huisvriend, p. 377; Private interview: P van Rensburg, former Town Clerk Calitzdorp Municipality - W Visser, 31 October 2013.

${ }^{98}$ Private interview: N Bailey, CIB administrator - W Visser, 31 October 2013.

${ }^{99}$ See CIB, Correspondence: M Hoogbaard - N Bailey, 22 Mei 2013; Ibid., Correspondence: N Bailey - M Hoogbaard, 19 Junie 2013; Ibid., Correspondence: M Hoogbaard - G Whitehead, 27 Julie 2013; Ibid., Correspondence: M Hoogbaard - Calitzdorp Besproeiingsraad, 16 Augustus 2013.

${ }^{100}$ Franco, et al., "The Global Politics of Water Grabbing”, pp. 1652-1653.

TD, 11(3), December 2015, pp. 186-207. 
farmers have a perpetual servitude on 400000 acre-feet $\left(493200000 \mathrm{~m}^{3}\right)$ of water in the dam for irrigation purposes. ${ }^{101}$

However, post-apartheid legislation has changed the nature of water ownership in South Africa which also affects the nature of water contestations between the CIB and the Calitzdorp and Kannaland Municipalities. Under the Water Act, No. 54 of 1956, a policy of water supply management was established but under the National Water Act (NWA), No. 36 of 1998, there was a shift from supply management to demand management. ${ }^{102}$

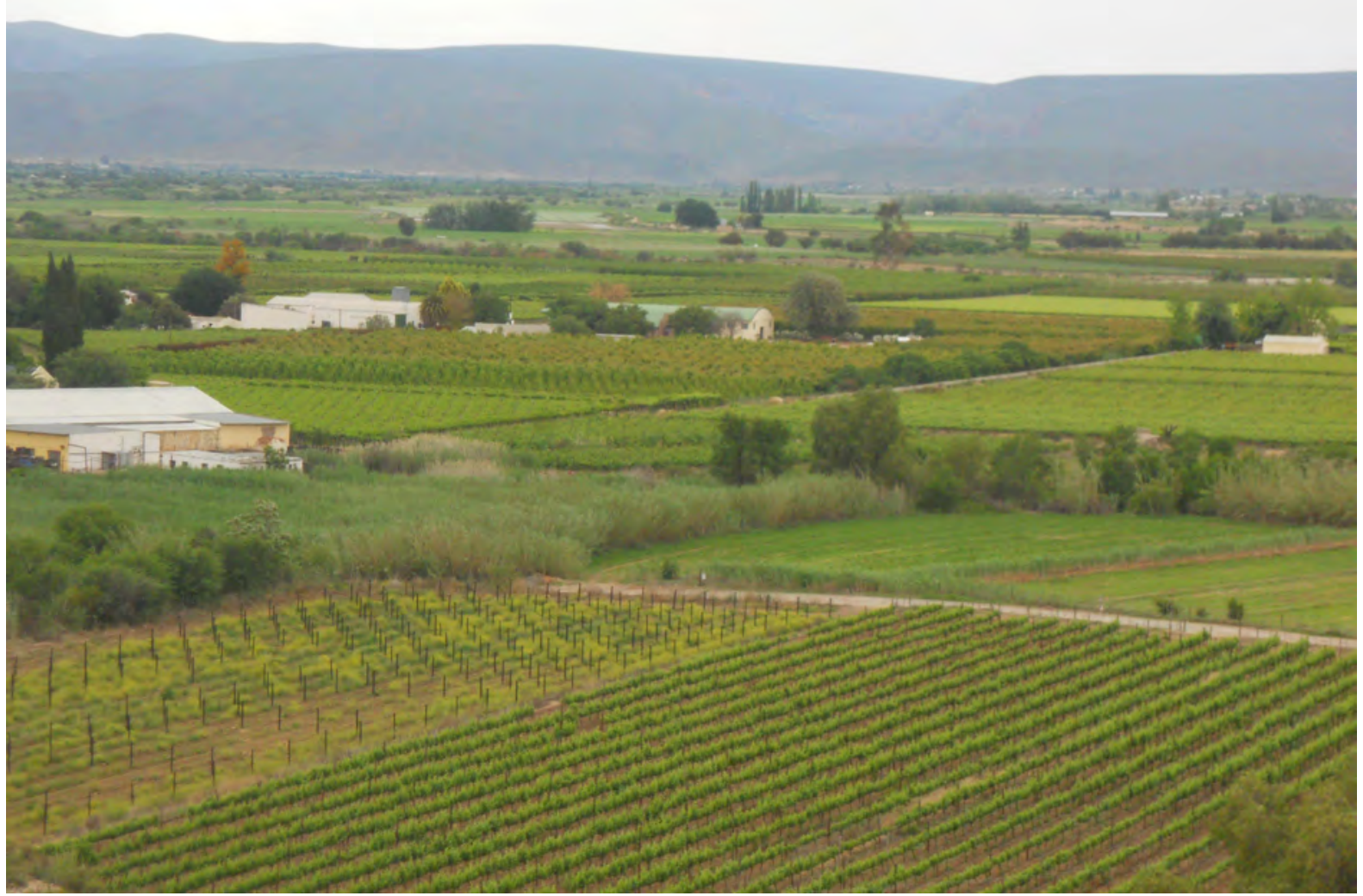

Illustration 4 Irrigated lands on the Gamka plains south of Calitzdorp (Source: Author's private collection)

Through the NWA the Roman Dutch and English common-law base of the South African water law dispensation, linking water-use rights inextricably to land access, had been wiped out. Water as a natural resource was removed from the sphere of private property. ${ }^{103}$ The NWA establishes an all-inclusive principle for all water resources on the need to protect basic human and ecological needs. Olowu explains that to this end, the NWA creates a "reserve" which is meant to implement the right to access to water guaranteed in the 1996 South

101 See CIB, Correspondence: Voorsitter Calitzdorp Besproeiingsraad - Voorsitter Calitzdorp Inwonersverening, 5 April 2005 and WCARS, WAD, Vol. 617, No. 925/MI, Correspondence: Town Clerk Calitzdorp Municipality - Director of Irrigation, 2 July 1934.

102 Lumby, et al., "The management of South Africa's water resources”, p. 83.

103 E van der Schyff and G Viljoen, "Water and the public trust doctrine - a South African perspective", The Journal for Transdisciplinary Research in Southern Africa, Vol. 4, No. 2, December 2008, pp. 340341. 
African Constitution. This reserve primarily creates a basic human needs reserve, which provides for the essential needs of individuals served by the water resource in question and includes water for drinking and other domestic purposes. This established right by the NWA regime supersedes all other uses of water. In other words, the amount of water required for the reserve must be guaranteed before water resources are allocated to other water users, ${ }^{104}$ such as irrigators.

The prognosis by Le Maitre, et al., is that the projected trends of water balance for the Little Karoo will lead to increasing deficits by 2025. ${ }^{105}$ And according to Hedden and Cilliers, South Africans currently use $27 \%$ more municipal water than could be expected given the size of the country's urban population. This could imply that more water from may be reallocated from irrigation to other (urban) use in certain areas in future. ${ }^{106}$ Although Van der Schyff and Viljoen state that legal title to water as public property now vests in the state, they also argue that the government's title to the country's water resources is severely restricted. ${ }^{107}$ The CIB, which obtained rights to the water in the Calitzdorp Dam as proclaimed by the Irrigation Act of 1912, had no statutory obligations to provide water to the Calitzdorp Municipality or to its successor, the Kannaland Municipality. The board granted a free water allocation voluntarily on request by the municipality in 1916. According to CIB estimates this means that each Calitzdorp inhabitant (2015 census) receives about $55 \mathrm{~K}$ free water on a daily basis. ${ }^{108}$

This article has emphasised the crucial importance of the Calitzdorp Dam as the only sustainable water source to the town ${ }^{109}$ and as a prerequisite for a viable agricultural economy in the district. However, in July 2015 the parliamentary Portfolio Committee on Water and Sanitation declared its intention that a national water master plan should be completed as "a tool to remedy the largely skewed history in relations to water rights in the country which remains the basis for most problems within the sector". The committee also stated that it was its "considered view that despite various interventions through policy and legislation the country's water rights regime remains largely skewed leaving government at the mercy of private owners of this resource." The committee is of the view that there is a need for a speedy review of the National Water Act and Services Act to address the issues of inequity within the sector "to be in line with the constitutional requirement of water being a human right". ${ }^{110}$ Should local government claim a larger water allocation from the CIB by statutory means in future, due to population growth and the hydrological insecurity of the region, the contestations over ownership of this water source could well be tested in the Constitutional Court, which could probably be the first of its kind.

D Olowu, "Privatisation and water governance in Africa: implications of a rights-based approach", The Journal for Transdisciplinary Research in Southern Africa, Vol. 4, No. 1, July 2008, p. 79.

Le Maitre, et al., "Water resources in the Klein Karoo", p. 47.

Hedden and Cilliers, "Parched prospects", pp. 8, 11.

Van der Schyff and Viljoen, "Water and the public trust doctrine", pp. 344, 346.

Communique from Mrs N Bailey, CIB administrator, 25.6.2015.

See WCARS, WAD, Vol. 617, No. 925/MI, Correspondence: Town Clerk Calitzdorp Municipality Director of Irrigation, 2 July 1934.

South Africa: Skewed water rights the real challenge. http://allafrica.com/stories/201507160586.html [Accessed on 20.7.2015].

TD, 11(3), December 2015, pp. 186-207. 